\title{
PELAKSANAAN TUGAS DAN FUNGSI KEPALA SEKOLAH PENDIDIKAN MENENGAH NEGERI
}

\author{
Hendrikus Nai ${ }^{1 *}$, Wiwik Wijayanti ${ }^{2}$ \\ 1SMP Negeri 2 Tanah Merah Boven Digoel-Papua \\ 2Universitas Negeri Yogyakarta
}

1Jl. Van Kan WET, Sokanggo, Mandobo, Boven Digoel, Prov. Papua, 99663, Indonesia

1J1. Colombo No. 1, Depok, Sleman 55281, Yogyakarta, Indonesia

* Corresponding Author. Email: hendrikusnai@gmail.com

\begin{abstract}
Abstrak
Tujuan penelitian ini adalah untuk mengetahui pelaksanaan tugas dan fungsi kepala sekolah dalam hal pengarahan, pengambilan keputusan, dan pendelegasian wewenang serta pengembangan sekolah. Penelitian ini menggunakan pendekatan kualitatif dengan jenis fenomenologi.Teknik pengumpulan data menggunakan teknik observasi, wawancara dan studi dokumen. Analisis data yang digunakan adalah model analisis interaktif Milles \& Huberman untuk mendeskripsikan dan menganalisis empat aspek pelaksanaan tugas dan fungsi kepala sekolah yang dijalankan pada kedua sekolah tersebut. Penelitian ini menghasilkan empat temuan utama. Pertama, pengarahan dan pemberian motivasi oleh kepala sekolah pada umumnya dilakukan pada saat upacara bendera dan rapat bersama dewan guru. Kedua, pengambilan keputusan oleh kepala sekolah dilakukan melalui rapat dewan guru dan karyawan sekolah. Ketiga, Pendelegasian wewenang kepala sekolah menengah negeri di Tanah Merah Kabupaten Boven Digoel Papua dilakukan secara formal, non formal dan pendelegasian otomatis.. Keempat, program pengembangan sekolah belum dilakukan secara maksimal oleh kepala sekolah.
\end{abstract}

Kata kunci: tugas dan fungsi, kepala sekolah, sekolah menengah negeri

\section{THE IMPLEMENTATION OF DUTIES AND FUNCTIONS OF STATE HIGH SCHOOL PRINCIPALS}

\begin{abstract}
The purpose of this study was to determine the school principal implementation of duties and functions: directing done by the principal, the decision made by the principal, the delegation of authority made by the principal, and the development of schools. This was a qualitative study using phenomenology approach. Data collection technique used observation, interview and document study. Analysis of the data used was an interactive model Miles $\mathcal{E}$ Huberman to describe and analyze four aspects of leadership that run on two schools. This research results in four major findings. First, guidance and motivation by principals are generally performed at a flag raising ceremony and meeting with the teachers. Second, the decision made by the school's principal was done through meetings by teachers and school employees. Third, the delegation of authority from school principal in the state high schools in Tanah Merah District Digoel Papua is done formally, non formally and automatically. Fourth, school development has not been done maximally yet by the school's principal.
\end{abstract}

Keywords: Duties and function, school principal, high school

Permalink/DOI: http://dx.doi.org/10.21831/amp.v6i2.10182 


\section{Pendahuluan}

Dalam UUD 1945 pasal 30 ayat 1 menegaskan (Republik Indonesia, 1945) "Setiap warga negara berhak mendapatkan pendidikan" Dengan kata lain, pendidikan diselenggarakan tanpa membeda-bedakan suatu golongan atau kelompok baik di daerah perkotaan maupun di daerah pedesaan, baik bagi golongan kaya maupun dari golongan tidak mampu dan dari golongan lainnya. Mengingat pendidikan diselenggarakan dengan menggunakan prinsip berkeadilan, demokratis, dan dilaksanakan secara merata di seluruh nusantara. Untuk dapat menjamin terlaksananya prinsip-prinsip tersebut, seorang kepala sekolah harus benar-benar memahami tugas pokok dan fungsinya di sekolah. Perubahan-perubahan kebijakan di bidang pendidikan harus mudah diakses di daerah-daerah terpencil seperti di pedalaman-pedalaman Papua, untuk menjamin pemerataan kualitas pendidikan. Untuk itu, kita bisa membayangkan untuk menjadi kepala sekolah di daerah yang serba sulit dibutuhkan ketahanan mental, daya juang dan semangat pengabdian yang tinggi. Kemampuan menjalankan tugas dan fungsi kepala sekolah yang optimal di daerah-daerah tersebut tentunya tidak semudah membalikkan telapak tangan. Pada tahun 2004 pemerintah daerah kabupaten Boven Digoel berani mendirikan sekolah untuk pendidikan menengah yakni SMA Negeri 1 Tanah Merah dan SMK Negeri 1 Tanah Merah. Pendirian kedua sekolah tersebut mendapat animo yang begitu besar dari masyarakat sampai saat ini, sehingga perlu dijamin kualitasnya dengan menempatkan seorang kepala sekolah yang berkompeten dalam menjalankan tugas dan fungsinya dengan baik.

Kenyataan bahwa masih ada beberapa daerah-daerah terpencil di Papua, termasuk di Tanah Merah Kabupaten Boven Digoel yang kurang optimal dalam menyelenggarakan pendidikan tidak dapat dipungkiri. Hal ini perlu menjadi perhatian serius jika kita ingin menyelenggarakan pendidikan yang setara dengan pendidikan di negara lain. Mengingat Indonesia merupakan negara kepulauan yang setiap dae- rahnya memiliki kondisi geografis yang berbeda-beda. Jadi, tidak heran apabila di suatu daerah dapat menyelenggarakan pendidikan yang berkualitas dengan memiliki komponen-komponen pendidik yang menunjang, namun di daerah lainnya masih kurang optimal dalam memanfaatkan komponen pendidikan yang dimilikinya untuk menunjang penyelenggaraan pendidikan yang berkualitas. Tidak dapat dipungkiri, letak geografis dan sumber daya yang terdapat di daerah tersebut merupakan faktor yang mempengaruhi kualitas pendidikan yang diselenggarakan.

Permasalahan utama pelayanan pendidikan pada dasarnya berkaitan dengan peningkatan efektivitas kepemimpinan kepala sekolah. Kepemimpinan kepala sekolah sangat tergantung pada berbagai aspek, yaitu lingkungannya, sarana prasarananya, bagaimana pola penyelenggaraannya (tata laksana), dukungan sumber daya manusia, dan kelembagaan serta adanya konsep-konsep yang akurat dan jelas. Hal tersebut dapat dilihat melalui implementasi pengelolaan manajemen oleh seorang kepala sekolah di sekolah yang dipimpinnya.

Berdasarkan permasalahan di atas, maka peneliti tertarik melakukan penelitian terkait dengan Tugas dan fungsi kepala sekolah menengah negeri di Tanah Merah Kabupaten Boven Digoel, Papua. Penelitian ini fokus pada tugas fungsi kepala sekolah dalam memberikan pengarahan, mengambil keputusan, mendelegasikan wewenang, dan mengembangkan sekolahnya.

Berkaitan dengan fungsi kepemimpinan kepala sekolah, Leithwood \& Duke (Chen, 2013, p. 303) mendefinisikan sebagai berikut: (a) Instructional influencing teachers in ways that will impact students' learning; (b) transformational increasing the commitment and capacity of staff; (c) moral appealing to others by appealing to notions of right and wrong; (d) Participative (involving other members of the school community beyond the Principal; (e) Managerial (operating the school efficiently; (f) Contingent adapting behavior to fit the situation.

Kepala sekolah sebagai pimpinan di sekolah memiliki tanggung jawab penting 
dalam usahanya mewujudkan visi, misi, dan tujuan sekolah. Oleh karena itu, menurut fungsinya, seorang pemimpin yakni kepala sekolah memiliki tugas-tugas penting.

Berkaitan dengan fungsi seorang kepala sekolah sebagai konselor, Wahab (2008, p. 95) mengatakan sebagai berikut, "Setiap dan semua pemimpin harus siap dan bersedia memberikan kesempatan kepada anggota organisasi untuk berkonsultasi dalam mengatasi/menyelesaikan masalah-masalah yang berhubungan dengan pekerjaan. Disamping itu juga tidak mustahil berkonsultasi mengenai masalah-masalah pribadi yang berhubungan langsung atau tidak langsung dengan pekerjaan".

Berdasarkan pendapat di atas maka dapat ditarik kesimpulan bahwa pada bagian fungsi sebagai konselor, kepala sekolah hendaknya menjadi rekan kerja dan teman bagi guru agar dapat menjalin komunikasi. Komunikasi yang terjalin baik akan semakin membuka kesempatan untuk saling terbuka terhadap berbagai permasalahan yang dihadapi untuk dicari solusi terhadap permasalahan tersebut.

Kepala sekolah sebagai instruktur hendaknya mempunyai peran sebagai guru yang bijaksana, yang memungkinkan setiap bawahan semakin lama semakin profesional dalam melaksanakan tugasnya. Seorang bawahan tentu dalam proses melaksanakan tugas tidak terlepas dari kesalahan. Oleh karena itu, kepala sekolah penting memposisikan diri sebagai instruktur untuk senantiasa mengarahkan guru dan staf dalam melaksanakan tugas di sekolah.

Kepala sekolah hendaknya memiliki kemampuan yang profesional khususnya dalam mengelola guru maupun staf di sekolah. Berkaitan dengan kemampuan profesional yang hendaknya dimiliki oleh seorang kepala sekolah, Danim (2006, p. 218) mengatakan sebagai berikut, "Kemampuan yang harus dimiliki pemimpin pendidikan antara lain membangkitkan inspirasi guru, menciptakan kerjasama antarguru, menciptakan kerjasama antarstaf, mengembangkan program supervise, mengelola kegiatan pembelajaran, mengatur program pengembangan, dan melaksanakan kegiatan lain yang erat kaitannya dengan pencapaian tujuan pendidikan.

Kepala sekolah memiliki peran penting dalam kegiatan rapat di sekolah. Kepala sekolah memposisikan diri sebagai pengarah, membantu guru sampai pada pengambilan keputusan yang dapat dipahami oleh setiap orang dan dapat diterima oleh seluruh bawahannya. Kegiatan rapat yang dilakukan di sekolah khususnya tentu tidak terlepas dari proses kepemimpinan kepala sekolah. Oleh karena itu, kepala sekolah memiliki peran penting dalam memimpin rapat, mendengarkan aspirasi para guru, dan membantu mengatasi permasalahan-permasalahan yang dibahass di dalam rapat.

Berkaitan dengan tugas kepala sekolah sebagai pemimpin rapat, Stoner (Wahjosumidjo, 1999, pp. 41-42) mengatakan dua fungsi pokok kepala sekolah, yakni: (1) Task related atau problem solving function, dalam fungsi ini pemimpin memberikan saran dalam pemecahan masalah serta memberikan sumbangan informasi dan pendapat; (2) Group maintenance function atau social function meliputi: pemimpin membantu kelompok beroperasi lebih lancer, pemimpin memberikan persetujuan atau melengkapi anggota kelompok lain, misalnya menjembatani kelompok yang sedang berselisih pendapat, memperhatikan diskusi-diskusi kelompok. Seorang pemimpin yang efektif adalah seorang pemimpin yang mampu menampilkan kedua fungsi tersebut dengan jelas.

Kepala sekolah juga memiliki tugas yang sangat penting dalam pengambilan keputusan, karena keberhasilan seorang pemimpin sangat ditentukan oleh keterampilan dalam pengambilan keputusan. Proses pengambilan keputusan tersebut akan berdampak luas terhadap mekanisme organisasi yang dipimpinnya. Berkaitan dengan pengambilan keputusan, Usman (2014, p. 441) mengatakan bahwa "Proses pengambilan keputusan meliputi tiga kegiatan, yaitu (1) kegiatan yang menyangkut pengenalan, penentuan, dan diagnosis masalah; (2) kegiatan yang menyangkut pengembangan alternatif pemecahan masalah; (3) 
kegiatan yang menyangkut evaluasi dan memilih pemecahan terbaik.

Pendapat tersebut di atas didukung pula oleh pendapat Wahab (2008, p. 92) yang mengatakan bahwa "dalam fungsi pengambilan keputusan sebagai pelaksanaan strategi kepemimpinan, agar lebih akurat dalam kepemimpinan untuk mengefektifkan organisasi, seorang pemimpin perlu mengikutsertakan anggota organisasi, sesuai posisi dan tanggung jawabnya masingmasing".

Kepala sekolah tidak dapat mengerjakan sendiri seluruh pekerjaan di sekolah, oleh karena itu kepala sekolah yang baik tentulah mendelegasikan sebagian tugas dan wewenang kepada bawahannya. Pendelegasian tugas dan wewenang ini bertujuan agar jalannya organisasi tidak mengalami kendala, dan terhindar dari unsurunsur penyalahgunaan wewenang. Berdasarkan pengertian tentang arti kepemimpinan di atas dapat diambil pengertian secara komprehensif yaitu pemimpin adalah pribadi yang memiliki kecakapan khusus atau superioritas tertentu, sehingga pemimpin memiliki kewibawaan dan kekuasaan untuk menggerakkan orang lain, serta pemimpin harus berpengetahuan yang luas, dan bervisi jauh ke depan serta memenuhi syarat-syarat tertentu dan mampu mempengaruhi kegiatan-kegiatan anggota kelompoknya.

Definisi tentang kepemimpinan menjadi hal yang penting untuk dikaji lebihj dalam, karena kajian tentang kepemimpinan bukan merupakan pembahasan baru. Oleh karena itu, penelitian ini akan menyajikan beberapa definisi kepemimpinan dari berbagai literatur yang diperoleh peneliti diantaranya (Usman, 2012, p. 3): mengatakan, "kepemimpinan adalah proses mempengaruhi orang lain agar berperilaku seperti yang diharapkannya untuk mencapai tujuan akhir organisasi". Lebih lanjut juga disampaikan oleh Bush (Usman, 2014, p. 311) mengatakan, "Kepemimpinan adalah tindakan-tindakan mempengaruhi orang lain untuk mencapai tujuan akhir yang diharapkan". Kepemimpinan menurut Sharma (Usman, 2014, p. 308) adalah: (1) tindakan- tindakan yang mempengaruhi orang lain untuk mencapai tujuan akhir yang diharapkan; (2) mempengaruhi masyarakat, bawahan, institusi-institusi, dan siswa; (3) bimbingan mewujudkan yang abstrak seperti visi dan sebagainya; (4) membujuk bawahan untuk menyampaikan minatnya

Selznick (Wahjosumidjo, 2003, pp. 4247) mengatakan ada empat macam tugas penting seorang pemimpin yaitu: (1) mendefinisikan misi dan peran organisasi (involves the definiton of the institutional organizational mission and role), (2) pengejawantahan tujuan organisasi (the institutional embodiment of purpose), (3) mempertahankan keutuhan organisasi (to defend the organzation's integration), (4) mengendalikan konflik internal yang terjadi di dalam organisasi (the ordering of internal conflict).

Fungsi utama pemimpin pendidikan menurut Rosmiati dan Kurniady (Tim Dosen Administrasi Pendidikan Universitas Pendidikan Indonesia, 2013, p. 126) sebagai berikut: (a) membantu terciptanya suasana persaudaraan, kerjasama, dengan penuh rasa kebebasan; (b) pemimpin membantu kelompok untu mengorganisir diri yaitu ikut serta dalam memberikan rangsangan dan bantuan kepada kelompok dalam menetapkan dan menjelaskan tujuan, (c) Pemimpin membantu kelompok dalam menetapkan prosedur kerja, yaitu membantu kelompok dalam menganalisis situasi untuk kemudian menetapkan prosedur mana yang paling prktis dan efektif, Pemimpin bertanggung jawab dalam mengambil keputusan bersama dengan kelompok, (d) Pemimpin memberi kesempatan kepada kelompok untuk belajar dari pengalaman. Pemimpin mempunyai tanggungjawab untuk melatih kelompok menyadari proses dan isi pekerjaan yang dilakukan dan berani menilai hasilnya secara jujur dan objektif, (e) Pemimpin bertanggung jawab dalam mengembangkan dan mempertahankan eksistensi organisasi.

Berdasarkan ketiga pendapat tentang fungsi kepemimpinan tersebut, penulis menyimpulkan bahwa fungsi kepemimpinan adalah menciptakan struktur untuk pencapaian tujuan, bertanggung jawab dalam 
mengembangkan organisasi, mempertahankan dan mengamankan integritas organisasi, serta mendamaikan perbedaan yang terjadi dalam kelompok menuju ke arah kesepakatan bersama.

Prinsip-prinsip kepemimpinan abad ke-21 Menurut Reinhartz \& Beach (Usman, 2014, pp. 407-412) sebagai berikut: (1) Kepemimpinan harus dapat dipercaya (credible), (2) Kepemimpinan harus menggunakan kebenaran, (3) Kepemimpinan harus menggunakan pengetahuan nilai inti bersama, (4) Kepemimpinan harus mendengarkan seluruh suara guru, siswa, staf, orang tua, dll, (5) Kepemimpinan harus menghasilkan visi yang baik, (6) Kepemimpinan harus berdasarkan data yang benar, (7) Kepemimpinan harus berjalan dengan introspeksi dan refleksi, (8) Kepemimpinan harus memberdayakan dirinya sendiri dan orang lain, serta melibatkan orang lain dalam informasi dan pengambilan keputusan, (9) Kepemimpinan melibatkan pengidentifikasian dan perlakuan terhadap hambatanhambatan personal dan organisasional untuk berubah.

Kepemimpinan kepala sekolah yang efektif dimulai dari melaksanakan visi, misi dan tujuan pendidikan. Ketiga hal tersebut menjadi indicator efektivitas kepemimpinan kepala sekolah. Berdasarkan hal tersebut, Mendels (2012, p. 55) mengatakan, "Effective leadership begins with the development of a schoolwide vision of commitment to high standards and the success of all students. The principal helps to spell out that vision and get all others on board with it". Pendapat tersebut jelas menegaskan bahwa pentingnya untuk mewujudkan visi, misi, dan tujuan sekolah dengan strategi menempatkan setiap sumber daya manusia, yakni guru dan staf pada posisi yang sesuai dengan kemampuan. Penyesuaian antara tugas dan kompetensi yang dimiliki ini akan sangat berpengaruh terhadap pelaksanaan kinerja. Oleh karena itu, kepala sekolah diharapkan bisa melihat potensi yang ada di sekolah sebagai sumber daya manusia yang akan menunjang keberhasilan pencapaian visi, misi, dan tujuan sekolah.
Triana (2015, p. 171) dalam bukunya Perilaku Organisasi menyatakan, "Kepala sekolah sebagai pimpinan lembaga pendidikan formal memiliki tugas dan tanggung untuk mengelola segala sumber daya untuk mencapai tujuan pendidikan". Kepala sekolah merupakan salah satu komponen pendidikan yang paling berperan dalam meningkatkan kualitas pendidikan. Untuk itu kepala sekolah harus mengetahui tugastugas yang harus ia laksanakan. Adapun tugas-tugas dari kepala sekolah seperti yang dikemukakan Wahjosumidjo (2003, p. 97) adalah sebagai berikut. Kepala sekolah bekerja dengan dan melalui orang lain. Kepala sekolah bertanggung jawab dan mempertanggungjawabkan. Kepala sekola bertindak dan bertanggungjawab atas segala tindakan yang dilakukan oleh bawahan. Perbuatan yang dilakukan oleh para guru, siswa, staf, dan orang tua siswa tidak dapat dilepaskan dari tanggung jawab kepala sekolah.

Hermino (2014, p. 128) menyatakan bahwa Kepala sekolah dapat bertindak sebagai konsultan bagi guru-guru, berusaha meningkatkan kemampuan staff, melibatkan kelompok dalam mengambil keputusan, dan mampu melakukan perubahan program pendidikan yang berdasarkan evaluasi dan perencanaan kelompoknya, serta memberi kesempatan setiap orang untuk berpartisipasi dalam program pengajaran.

Berkaitan dengan visi, Kaya (2015, p. 600) mengatakan, "Vision serves three important functions by clarifying the general direction of change: telling where to go, simplifying hundreds or thousands of more detailed decisions, and helping to quickly and efficiently coordinates". Lebih lanjut dalam sebuah organisasi dibutuhkan adanya kerja sama yang baik. Maka dari itu, Mensoor, Danial, Javad, et al. (Kaya, 2015, p. 600) mengatakan, sebagai berikut. Organizations cannot achieve competitive advantage over others just by offering products or delivering services in which we realize human resource undoubtedly plays a vital role. That is the reason why today many organizations are paying great attention to employee engagement and motivate employees to achieve organizational goals effectively. 
Berdasarkan pendapat di atas, maka dapat ditarik kesimpulan bahwa visi sekolah hanya akan terwujud apaila terciptanya kerjasama yang baik di sekolah. Kerjasama yang baik antara kepala sekolah dengan bawahan, maupun antar bawahan. Dengan demikian, Tujuan sekolah guna mewujudkan tujuan pendidikan nasional dapat terselenggara melalui lembaga sekolah.

\section{Metode Peneitian}

Jenis penelitian ini adalah kualitatif yang mengadopsi model Miles \& Huberman (1994, p. 10). Penelitian dilakukan di Tanah Merah Kabupaten Boven Digoel, Papua sebagai lokasi penelitiannya. Objek penelitiannya fokus pada sekolah menengah negeri di daerah tersebut. Sekolah yang dimaksud adalah SMA Negeri 1 Tanah Merah dan SMK Negeri 1 Boven Digoel. Penelitian dilakukan selama kurang lebih empat bulan, mulai 08 Januari-26 April 2016.

Unit analisis yang digunakan dalam penelitian ini adalah kelembagaan. Mengingat penelitian ini difokuskan pada kepala sekolah menengah negeri di Tanah Merah Kabupaten Boven Digoel, Papua, maka secara rinci unit analisisnya adalah pelaksanaan tugas dan fungsi kepala sekolah pada 2 sekolah menengah negeri di daerah tersebut. Kedua sekolah menengah negeri tersebut terdiri dari SMA Negeri 1 Tanah Merah, dan SMK N 1 Boven Digoel.

Sumber data utama dalam penelitian ini adalah kata-kata dan tindakan kepala sekolah menengah negeri di Tanah Merah Kabupaten Boven Digoel, Papua. Data akan dihimpun melalui observasi, wawancara, dan studi pustaka yang terkait dengan pelaksanaan tugas dan fungsi kepala sekolah. Selain itu, diperlukan juga data dari para pendidik dan tenaga kependidikan sebagai data tambahan yang mampu memberikan gambaran tentang pelaksanaan tugas dan fungsi kepala sekolah di sekolah menengah negeri tersebut.

Pengukuran keabsahan data dilakukan dengan trianggulasi yakni untuk melakukan validasi terhadap data-data penelitian yang telah didapatkan di lapangan.
Analisis data dilakukan dengan proses mencari dan menyusun secara sistematis data yang diperoleh dari hasil wawancara, catatan lapangan, dan bahan-bahan lain, sehingga dapat mudah dipahami, dan temuannya dapat diinformasikan kepada orang lain (Sugiyono, 2015, p. 334).

\section{Hasil Penelitian dan Pembahasan}

Pengarahan

\section{SMA Negeri 1 Tanah Merah}

Fakta yang terjadi menunjukkan bahwa kegiatan pengarahan yang dilakukan oleh kepala sekolah pada sekolah menengah negeri di Tanah Merah, Kabupaten Boven Digoel-Papua dilakukan ketika rapat maupun upacara bendera di sekolah. Pengarahan seharusnya diberikan untuk peningkatan kualitas pembelajaran, disiplin siswa dan perbaikan proses belajar mengajar dalam kelas. Oleh karena itu, kegiatan pengarahan ini sangat penting dilakukan. Akan tetapi, kondisi yang terjadi adalah kegiatan pengarahan yang dirasakan oleh guru yang dilakukan oleh kepala sekolah masih sangat kurang dan terlalu umum. Selain itu pula, kegiatan evaluasi dan control yang seharusnya dilakukan, masih tidak dilakukan oleh kepala sekolah.

\section{SMK Negeri 1 Boven Digoel}

Fenomena yang terjadi dalam kegiatan pengarahan berlangsung lebih baik dibandingkan dengan SMA 1 Negeri Tanah Merah. Kepala sekolah di Sekolah SMA Negeri 1 Tanah Merah menanamkan pentingnya pengarahan diberikan kepada guru, staf dan siswa. Oleh karena itu, kepala sekolah senantiasa memberikan pengarahan, tidak hanya bersifat formal dalam situasi formal yakni rapat dan upacara, melainkan pengarahan bersifat personal kepada guru maupun siswa. Pengarahan yang diberikan disertai juga dengan praktik nyata yang diberikan oleh kepala sekolah. Dalam artian bahwa kepala sekolah tidak hanya memberikan perintah, melainkan juga melaksanakan secara langsung apa yang diperintah- 
kan tersebut, sehingga dapat diikuti oleh guru, staf dan juga siswa.

Fenomena mendukung pernyataan Wahab (2008, p. 93) mengatakan bahwa Setiap pemimpin harus memahami bahwa di dalam posisi dan perannya secara implicit terdapat kekuasaan dan/atau wewenang dan tanggung jawab, yang harus dijalankan secara efektif. Salah satu diantaranya ialah kekuasaan dan/atau wewenang memerintahkan anggotanya untuk melakukan sesuatu dalam melaksanakan tugas dan tanggung jawabnya sebagai anggota organisasi.

Pengambilan Keputusan

\section{SMA Negeri 1 Tanah Merah}

Kegiatan rapat yang dipimpin langsung oleh kepala sekolah kemudian mengevaluasi berbagai kegiatan yang telah dilaksanakan serta menyampaikan rencana-rencana kegiatan sekolah yang akan dilaksanakan untuk kedepannya. Laguerre (Bento \& Ribeiro, 2013, p. 122) mengatakan, "The leaders know and defend their values and take their decisions taking into consideration their values. The led ones identify in its leader a high level of self-conscience concerning the values, beliefs, emotions, self-identity and abilities". Mendukung pernyataan di atas, lebih lanjut diperkuat oleh Roux (Bento \& Ribeiro, 2013, p. 122) yang mengatakan bahwa The authentic leaders act in agreement with their deep values and personal convictions to construct the credibility, the respect and the confidence of its followers, stimulating diverse points of view and the construction of networks making that the followers recognize it as an authentic leader.

\section{SMK Negeri 1 Boven Digoel}

Pengambilan keputusan merupakan suatu hal yang sangat penting bagi individu maupun organisasi. Mengambil keputusan kadang-kadang mudah tetapi lebih sering sulit sekali. Kemudahan atau kesulitan mengambil keputusan tergantung pada banyaknya alternatif yang tersedia. Semakin banyak alternatif yang tersedia, kita akan semakin sulit dalam mengambil keputusan. Keputusan yang diambil memiliki tingkat yang berbeda-beda. Ada keputusan yang tidak terlalu berpengaruh terhadap organi- sasi, tetapi ada keputusan yang dapat menentukan kelangsungan hidup organisasi. Oleh karena itu, hendaknya mengambil keputusan dengan hati-hati dan bijaksana.

Berbeda dengan hasil penelitian di SMA Negeri 1 Tanah Merah. SMK Negeri 1 Boven Digoel memiliki manajemen kepemimpinan yang lebih baik khususnya dalam hal pengambilan keputusan rapat. Kepala sekolah menjadi pemimpin rapat mengambil keputusan tidak sepihak. Kepala sekolah berkolaborasi dengan guru, mendengarkan gagasan guru dan kemudian mengambil keputusan berdasarkan kesepakatan bersama

\section{Pendelegasian Wewenang \\ SMA Negeri 1 Tanah Merah}

Fenomena yang terjadi dalam hal pendelegasian wewenang sudah berjalan sebagaimana yang harus dilakukan oleh kepala sekolah. Akan tetapi, transparansi dalam pendelegasian wewenang ini belum terlihat dengan baik di sekolah tersebut. Dikatakan belum terlihat oleh karena, pendelegasian wewenang masih bersifat lisan tanpa ada penugasan tertulis yang diketahui oleh seluruh guru maupun staf di sekolah. Selain itu pula, pendelegasian wewenang tersebut masih tidak merata dilakukan oleh kepala sekolah. Hal tersebut menyebabkan sumber daya manusia juga tidak berkembang baik. Dikatakan tidak berkembang baik oleh karena tidak adanya kesempatan yang diberikan kepada guru untuk memegang tanggung jawab tertentu yang diberikan oleh kepala sekolah.

\section{SMK Negeri 1 Boven Digoel}

Pengorganisasian ini tidak hanya sekedar pendelegasian beban tugas dalam mengajar kepada guru seperti yang selama ini dilaksanakan di sekolah-sekolah yang kurang maju.Pengorganisasian tidak hanya sekedar membagi kedudukan tanpa jelas tolak ukur keberhasilan pelaksanaan dari tugas yang telah didelegasikan. Pengorganisasian meliputi semua tugas yang ada dan dalam hal ini dimulai dari penafsiran yang sama atas tujuan yang hendak dicapai se- 
hingga membantu memformulasikannya kedalam berbagai bidang dan menjelaskan siapa yang bertanggungjawab dalam pelaksanaannya. Selama ini pengorganisasian diterjemahkan dalam pengertian yang sangat sederhana dan tidak substansial. Pengorganisasian hanya sekedar membagi jam mengajar,memilih wali kelas,wakil Kepala sekolah tanpa diikuti oleh fungsi-fungsi lainnya, sehingga masing-masing pelaksana yang ditunjuk tidak memiliki program yang tepat guna dan berwawasan luas ke depannya.

Program Pengembangan Sekolah yang Meliputi Sumber Daya Manusia, Sarana dan Prasarana, dan Program Pembelajaran

\section{SMA Negeri Tanah Merah}

Pendidikan adalah usaha sadar yang dengan sengaja dirancangkan untuk mencapai tujuan yang telah ditetapkan. Pendidikan bertujuan untuk meningkatkan kualitas sumber daya manusia. Salah satu usaha untuk meningkatkan kualitas sumber daya manusia ialah melalui proses pembelajaran di sekolah.

Dalam usaha meningkatkan kualitas sumber daya pendidikan, guru merupakan komponen sumber daya manusia yang harus dibina dan dikembangkan terus-menerus. Pembentukan profesi guru dilaksanakan melalui program pendidikan prajabatan maupun program dalam jabatan. Tidak semua guru yang dididik di lembaga pendidikan terlatih dengan baik dan memenuhi kualifikasi. Potensi sumber daya guru itu perlu terus bertumbuh dan berkembang agar dapat melakukan fungsinya secara potensial. Selain itu pengaruh perubahan yang serba cepat mendorong guru-guru untuk terus-menerus belajar menyesuaikan diri dengan perkembangan ilmu pengetahuan dan teknologi serta mobilitas masyarakat.

\section{SMK Negeri 1 Boven Digoel}

Fenomena yang ada dalam hal pengembangan sumber daya manusia yakni guru sudah berjalan dengan baik. Pemerataan kesempatan untuk mengikuti pelatihan juga dilakukan oleh kepala sekolah. Selain itu, kepala sekolah juga memantau perkembangan guru untuk kemudian dilakukan evaluasi guna peningkatan berkelanjutan. Berkaitan dengan hal sarana dan prasarana, kepala sekolah juga terampil dalam menjalin kerjasama dengan pihak luar guna membantu menyediakan sarana dan prasarana yang akan menunjang proses belajar mengajar. Masalah pembiayaan di sekolah juga memiliki transparansi yang kemudian membuat para guru dapat bekerja dengan baik tanpa ada rasa curiga maupun ketidakpercayaan dari guru kepada pengelolaan keuangan dari kepala sekolah.

\section{Simpulan}

Berdasarkan deskripsi dan dan analisis data hasil wawancara, hasil pengamatan dan studi dokumen dapat disimpulkan bahwa pelaksanaan tugas dan fungsi kepala sekolah menengah negeri di Tanah Merah Kabupaten Boven Digoel Papua sebagai berikut.

Pengarahan dan pemberian motivasi oleh kepala sekolah pada umumnya dilakukan pada saat upacara bendera dan rapat bersama dewan guru. Perbedaanya terletak pada ketegasan kepala sekolah dalam mengendalikan guru-guru dan karyawannya.

Pengambilan keputusan oleh kepala sekolah dilakukan melalui rapat dewan guru dan karyawan sekolah. Perbedaannya terletak pada fungsi kontrol dan evaluasi yang dilakukan oleh kepala sekolah.

Pendelegasian wewenang kepala sekolah sekolah menengah negeri di Tanah Merah Kabupaten Boven Digoel Papua dilakukan secara formal, nonformal dan pendelegasian otomatis. Pendelegasian formal dilakukan melalui keputusan kepala sekolah dengan surat pendelegasian wewenang secara resmi. Pendelegasian nonformal dilakukan secara lisan, sedangkan pendelegasian otomatis adalah adalah kesepakatan bahwa jika kepala sekolah berhalangan otomatis wakil kepala sekolah urusan kurikulum mengambil alih tugas kepala sekolah.

Program pengembangan sekolah belum dilakukan secara maksimal oleh kepala sekolah. Sarana dan prasarana sekolah menengah negeri di Tanah Merah Boven 
Digoel Papua memenuhi standar dan cukup memadai dalam mendukung proses pembelajaran di sekolah. Namun terbatasnya kualitas sumber daya guru dan karyawan di sekolah menyebabkan tidak optimalnya pemanfaatan sarana dan prasarana tersebut dalam proses pembelajaran.

Kepala sekolah menengah negeri di semua tingkatan di Tanah Merah Boven Digoel Papua selalu melakukan program perbaikan pembelajaran di sekolah setiap awal semester dan awal tahun pelajaran. Namun jarangnya supervisi yang dilakukan menyebabkan program ini tidak berjalan optimal di sekolah. Pembinaan dan pengembangan staf atas inisiatif kepala sekolah tidak pernah dilakukan. Hal ini menyebabkan rendahnya kualitas sumber daya manusia di sekolah.

Saran-saran yang dapat disampaikan pada penelitian ini adalah sebagai berikut. Untuk kepala sekolah yang menjalankan tugas dan fungsinya dengan memimpin secara demokratis dengan gaya pengambilan keputusan yang partisipatif, seperti yang SMA Negeri 1 Tanah Merah, dan SMK Negeri 1 Tanah Merah, sebaiknya disertai dengan ketegasan kepala sekolah dalam menegakan disiplin guru, karyawan, dan siswa. Ketidaktegasan kepala sekolah nampak dari tidak disiplinnya guru dan karyawan dalam menjalankan tugasnya, yang berimbas juga pada ketidakdisiplinan siswa dalam mengikuti proses belajar-mengajar di sekolah. Hal ini menjadi akar masalah rendahnya mutu pendidikan di Kabupaten Boven Digoel.

Berikutnya, kepala sekolah sebaiknya adalah orang yang mampu menjalankan tugas dan fungsinya degan memimpin secara autokratif dengan gaya pengambilan keputusan yang direktif, namun harus mampu juga membangun komunikasi yang intensif dengan bawahan, memahami situasi, kondisi, dan karakter individu bawahannya supaya tidak tercipta jarak yang terlalu jauh antara bawahan dan atasan. Pengendalian diri seorang kepala sekolah dalam menghadapi setiap masalah juga sangat penting, supaya bawahan tidak merasa tertekan dan terpaksa dalam menjalankan tugas-tugasnya di sekolah.

Jika menjalankan tugas dan fungsinya dengan memimpin secara demokratis yang keputusannya partisipatif disertai ketegasan dan keteladanan, dan juga memimpin secara autoratif yang keputusannya direktif disertai pengendalian diri dan adanya komunikasi yang manusiawi, maka peningkatan mutu pendidikan sekolah menengah negeri di Tanah Merah Kabupaten Boven Digoel, Papua akan mengalami peningkatan yang signifikan.

\section{Daftar Pustaka}

Bento, A. V., \& Ribeiro, M. I. (2013). Authentic leadership in school organizations. European Scientific Journal, 9(31). Retrieved from https:// eujournal.org/index.php/esj /article/view/2051

Chen, W. (2013). School leadership in ICT implementation: Perspectives from Singapore. The Asia-Pacific Education Researcher, 22(3), 301-311. https:// doi.org/10.1007/s40299-0120055-8

Danim, S. (2006). Visi baru manajemen sekolah dari unit birokrasi ke lembaga akademik. Jakarta: Bumi Aksara.

Hermino, A. (2014). Kepemimpinan pendidikan di era globalisasi. Yogyakarta: Pustaka Pelajar.

Kaya, A. (2015). The relationship between spiritual leadership and organizational citizenship behaviors: a research on school principals' behaviors. Educational Sciences: Theory E Practice, 15(3). https://doi.org/10.12738/estp.2015.3. 1988

Mendels, P. (2012). The effective principal: five pivotal practices that shape instructional leadership. Feature Leadership, 33(1). Retrieved from http://www.wallacefoundation.org/ knowledge-center/Documents/TheEffective-Principal.pdf 
Miles, M. B., \& Huberman, A. M. (1994). Qualitative data analysis: an expanded source book. Thousand Oaks: Sage Publications, Inc.

Republik Indonesia. Undang-Undang Dasar Negara Republik Indonesia Tahun 1945 (1945).

Sugiyono. (2015). Metode penelitian pendidikan, pendekatan kuantitatif, kualitatif,dan RED. Bandung: Alfabeta.

Tim Dosen Administrasi Pendidikan Universitas Pendidikan Indonesia. (2013). Manajemen pendidikan. Bandung: Alfabeta.

Triana, C. (2015). Perilaku organisasi dalam pendidikan. Bandung: Remaja Rosdakarya Offset.
Usman, H. (2012). Kepemimpinan pendidikan kejuruan. Yogyakarta: UNY Press.

Usman, H. (2014). Manajeman: teori, praktik, dan riset pendidikan (4th ed.). Jakarta: PT Bumi Aksara.

Wahab, A. A. (2008). Anatomi organisasi dan kepemimpinan pendidikan. Bandung: Alfabeta.

Wahjosumidjo. (1999). Kepemimpinan kepala sekolah: tinjauan teoritik dan permaslahannya. Jakarta: Rajagrafindo Perkasa.

Wahjosumidjo. (2003). Kepemimpinan kepala sekolah: tinjauan teoritik dan permasalahannya. Jakarta: PT. Raja Grafindo Persada. 